\title{
Driving the Fourth Industrial Revolution Initiative Through University and Industry Collaborations
}

\author{
"Aliu John, Aigbavboa Clinton and Wellington Didibhuku Thwala
}

\begin{abstract}
First submission: 12 January 2020; Accepted: 1 November 2020; Published: 8 December 2021
To cite this article: Aliu John, Aigbavboa Clinton and Wellington Didibhuku Thwala (2021). Driving the fourth Industrial Revolution initiative through university and industry collaborations. Journal of Construction in Developing Countries, 26(2): 211-230. https://doi.org/10.21315/jcdc2021.26.2.10.
\end{abstract}

To link to this article: https://doi.org/10.21315/jcdc2021.26.2.10

\begin{abstract}
As the world basks in the euphoria of the fourth Industrial Revolution (4IR), Africa is gearing up for this innovative age, with South Africa as one of its leading voices. One of the ways of leveraging on the opportunities presented by the 4IR era is to foster collaborations between universities and the construction industry (university-industry collaboration, UIC). This research article aims to determine the positive impacts of UIC on the employability of built environment graduates. A qualitative Delphi approach was adopted to validate 16 factors, which were identified from literature. A total of 14 experts completed a twostage iterative Delphi study process and reached consensus on all 16 factors identified. This study found that networking activities with industry professionals, student's exposure to innovative ideas and 4IR training programme opportunities are some of the ways through which UIC can improve 4IR knowledge and employability skills among students. From the Delphi survey results, educational institutions have been placed under significant pressures to intensify collaborations with the industry by creating avenues for students to experience industrial training with present-day $4 \mathrm{IR}$-driven sectors such as the construction industry, which has begun the adoption of $4 I R$ elements into its processes to improve efficiency and productivity. Although the issue of UIC has been widely discussed in the body of knowledge, very few have incorporated the 4IR dimension as a gap, which this study aims to fill.
\end{abstract}

Keywords: Built environment, Collaboration, Employability skills, Fourth Industrial Revolution, Pedagogy

\section{INTRODUCTION}

Universities across the globe have continuously been viewed as training centers that can develop human capital, which eventually contributes to a country's development. Their roles in knowledge production have earmarked them as key drivers of innovation and "major agents of economic growth" (Rinaldi et al., 2018). However, their conventional pedagogical approaches are not enough as they seek to execute their educational activities and maintain a competitive advantage in a knowledge-seeking society (Etzkowitz and Zhou, 2017). One of the many ways through which universities can refresh and boost their academic structures is to reinforce collaborations with the construction industry due to its many positive impacts on built environment students. According to Aliu and Aigbavboa (2018), the symbiotic relationships between universities and the construction industry foster the diffusion of knowledge, improves research and

CIDB Centre of Excellence and Sustainable Human Settlement and Construction Research Centre, University of Johannesburg, Johannesburg, SOUTH AFRICA

*Corresponding author: Ajseries77@gmail.com 
development (R\&D) and create patent opportunities, thereby contributing to the economic development of any society. This study focuses on South Africa and seeks to determine the roles of university-industry collaboration (UIC) in driving the fourth Industrial Revolution (4IR) initiative. The objectives of this study align with some of South Africa's long term National Development Plans, which seek to "unite South Africans of all races and classes around a common programme to eliminate poverty and reduce inequality" and to "build a capable and developmental state" by the year 2030. This mandate also resonates with some of the Sustainable Development Goals (SDGs) proposed by the United Nations. Among the 17 SDGs, Goal 8 seeks to "promote sustained, inclusive and sustainable economic growth, full and productive employment, and decent work for all". Similarly, Goal 9 seeks to "build resilient infrastructure, promote inclusive and sustainable industrialisation and foster innovation". Both goals deal with innovativeness for economic progress, something which South Africa is currently advocating for with several proposed $4 I R$ initiatives in recent times.

In achieving the objectives of this study, a qualitative Delphi approach was adopted to validate the UIC factors as the latest wave of innovation gathers momentum across the globe. This article begins by discussing how university and construction industry collaborations can be used to drive the 4IR initiative in South Africa. Subsequently, the article reviews international literature on the positive roles of collaborations in developing built environment students as the world gears up for the 4IR. Although the issue of collaborations between university and academia has been previously discussed in the body of knowledge, very few studies have explored how such collaborations can be used to drive the 4IR movement, which has gathered momentum in recent times. This is the gap in knowledge that this article seeks to fill. Thus, the objective of this article was to bring to light the various ways through which UIC can propel the 4IR discussion in developing countries like South Africa. This study, therefore, contributed to the body of knowledge by introducing the 4IR component into the UIC discourse by engaging experts within the built environment in determining graduate employability. As developing nations like South Africa constantly seek ways to develop a competent future workforce that will leverage on the opportunities presented by the $4 \mid \mathrm{R}$, this study is timely as it emphasizes the need for students to get acquainted with 4IR technologies and their applications before graduation. The findings of this article are influential to the educational sectors of South Africa and beyond, most especially in the formulation and introduction of 4IR courses (modules), guidelines and philosophies for both private and public centres of higher learning. More so, the findings from this research provide academia with the opportunities of making knowledgeable decisions on their curricula, so that equipping students with $4 \mathrm{IR}$ knowledge is top of the agenda while seeking collaborations with the industry. The additional knowledge derived from this study will be beneficial in achieving a more realistic understanding of the roles of UIC in determining graduate employability is South Africa and beyond. 


\section{LITERATURE REVIEW}

\section{Driving the 4IR Initiative in South Africa}

As the world embraces the technologies of the 4IR, Africa is also gearing up for this wave of digitalisation, with South Africa as one of its leading voices. Since assuming office in 2018, the nation's president, Cyril Ramaphosa and his administration have spearheaded the 4IR march. During the inaugural Digital Economy Summit held at the Gallagher Convention Centre, Johannesburg on 5th July 2019, under the theme "Advancing the African Agenda on the Fourth Industrial Revolution through Digital Transformation", the president stated, "Given what we know today about the potential beneficial impacts of the 4IR, we must embrace this historic confluence of human insights and engagement, artificial intelligence and technology, to rise to the challenges of poverty, unemployment and inequality". President Ramaphosa went on to declare that "For the coming decade, this programme of transformation will be focused on growing the South Africa we want through the realisation of seven critical priorities that apply to all sectors of society. We should look at them through the prism of the 4IR and what the 4IR can enable us to do to address these seven priorities". This presidential mandate outlines the nation's willingness and readiness to become a major player in the $4 \mathrm{IR}$ era. Consequently, the president established a 30-member 4IR commission to work closely with the government by establishing policies and framework that will strategically position the nation to maximise 4IR opportunities to solve socio-economic issues (Ramaphosa, 2019).

The nation has also seen the establishment of 4IRSA, which is coined from a "partnership for the 4IR in South Africa". This partnership was designed in 2019 to stimulate a national dialogue to leverage on the opportunities provided by the 4IR for the benefit of the nation, with the 4IRSA partnership seeking active participation from the South African government, industry, researchers, small businesses, labour, academia, civil society, non-governmental organisations (NGO's), international organisations and the media. Founded by the Universities of the Witwatersrand in Johannesburg and the University of Fort Hare in the Eastern Cape, the 4IRSA partnership has since witnessed the inclusion of other partners such as Deloitte Africa, Department of Communications and Digital Technologies, Vodacom and Huawei. This platform also seeks to support and complement other 4IR initiatives proposed by Ramaphosa, most notably the recently formed Presidential Commission on the 4IR (4IRSA, 2019).

The 4IRSA partnership firmly relates to the triple helix (TH) of universityindustry-government relationship. This model refers to the interrelationships and internal transformations between the three cardinal pillars, university, industry and government, of achieving socio-economic development. In this model, the role of institutions of higher learning in attaining a knowledge-based society cannot be overstated (Ełzkowitz and Zhou, 2017). A summary of the model is shown in Figure 1. While universities are focused on teaching and research, the industry is fixated on executing knowledge for innovative designs. On the other hand, the government ensures seamless interaction between both by regulating industry activities and providing support systems for universities to carry out their duties. According to Leydesdorff (2013), the TH model highlights 
"the network overlay of communications and expectations that reshape institutional arrangements among universities, industries and governmental agencies" (Leydesdorff, 2013).

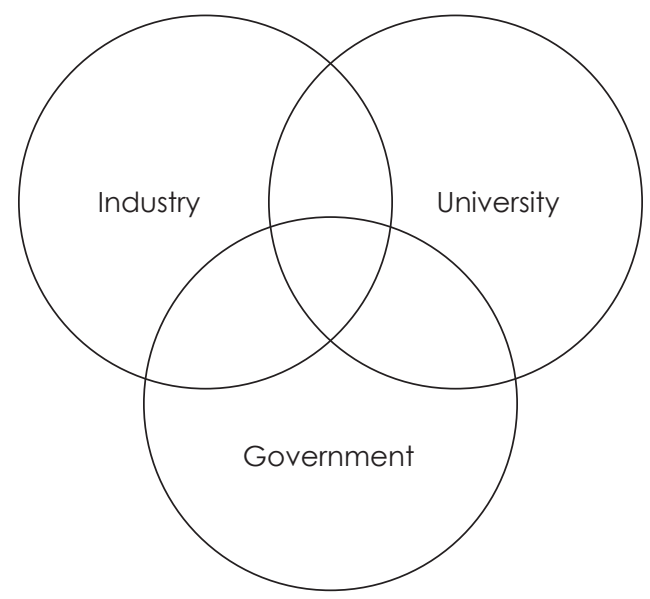

Figure 1. The TH of university-industry-government relationship Source: Leydesdorff (2013)

As shown in Figure 1, a knowledge-based society can be achieved by an effective university-industry-government relationship. This applies to the position of 4IR in South Africa, upon which the 4IRSA partnership seeks to thrive. This platform seeks active participation from the government, industry, researchers, small businesses, labour, academia, civil society, NGOs, international organisations and the media. The contributions of these various sectors are expected to propel the $4 \mathrm{IR}$ discussion and to complement other 4IR initiatives that have been proposed by Ramaphosa.

\section{International Studies on UIC}

The positive impacts of UIC on the employability of built environment graduates have been discussed extensively across the globe in recent times. In developing countries, effective collaborations between both parties can provide scholarship opportunities for students to embark on further studies (Belfield, 2012; Guimón, 2013; Ivascu, Cirjaliu and Draghici, 2016). Due to this innovative era coupled with skyrocketing costs of education, universities can collaborate with industry, which can lead to the provision of funding, grants and scholarships for students to acquire further education. This is related to the studies of both Bozeman and Gaughan (2007) and Link, Siegel and Bozeman (2017), who submitted that research grants obtained from the construction industry can improve the activities of universities as students are adequately supported in their quest to acquire scientific knowledge. By gaining scientific knowledge, students can contribute to the body of knowledge by writing scholarly articles and publications with industry professionals, hence improving their employability skills (Lundberg et al., 2006). More so, studies in Chile and Colombia have established that through 
collaborations, universities can expose students to the world of work, which can stimulate the invention of new products, hence increasing their research outputs and even patenting opportunities (Ankrah and Omar, 2015; Marotta et al., 2007). In agreement, Kamp and Milke (2019) pointed out that through collaborations, there exists a diffusion of knowledge from industry professionals to students, thereby providing mentorship opportunities and providing students with the knowledge required to thrive in their chosen careers to succeed in the world of work. More so, the presence of industry mentorship encourages career development and outcomes among students, hence employability improvement is guaranteed (Aasheim, Li and Williams, 2009). Hariharasudan and Kot (2018) further submitted that collaborations could improve R\&D undertakings in universities as they are exposed to industry activities and professionals who constantly seek new ways to improve their processes. Furthermore, through collaborations, students are provided with many opportunities to embark on field trips. This pedagogical teaching method involves sponsoring students to industrybased activities with the intent of acquiring valuable learning experience under the supervision of their supervisors (DeWitt and Storksdieck, 2008; Dori and Tal, 2000; Short and Lloyd, 2017). More so, field trips are outings and excursions that provide enhanced learning for students as well as increased practical knowledge of their subject area (Bamberger and Tal, 2008; Plutino, 2016). It is based on this wealth of knowledge that the different roles of UIC in developing the employability of built environment graduates as shown in Table 1 were assessed in this study.

Table 1. UIC benefits for students

\begin{tabular}{|c|c|c|}
\hline Code & UIC Factors & Literature Sources \\
\hline $\mathrm{UICl}$ & Scholarship opportunities for students & $\begin{array}{l}\text { Guimón (2013), Ivascu, Cirjaliu and } \\
\text { Draghici (2016) }\end{array}$ \\
\hline UIC2 & $4 I R$ job opportunities for graduates & Nyawo and Mashau (2019) \\
\hline UIC3 & Research grants from industry & $\begin{array}{l}\text { Bozeman and Gaughan (2007) and } \\
\text { Ivascu, Cirjaliu and Draghici (2016) }\end{array}$ \\
\hline UIC4 & Inclusion of open-day events & $\begin{array}{l}\text { Roberts and Kozlowski (2001) and } \\
\text { Plutino (2016) }\end{array}$ \\
\hline UIC5 & Field trips to industry & $\begin{array}{l}\text { Dori and Tal (2000) and Lawson } \\
\text { et al. (2011) }\end{array}$ \\
\hline UIC6 & Industry mentoring for students & Kamp and Milke (2019) \\
\hline UIC7 & Vocational training & Hyland (2019) \\
\hline UIC8 & Guest speakers from industry & $\begin{array}{l}\text { Roberts and Kozlowski (2001) and } \\
\text { Mei (2019) }\end{array}$ \\
\hline UIC9 & $\begin{array}{l}\text { Networking activities with industry } \\
\text { professionals }\end{array}$ & Aasheim, Li and Williams (2009) \\
\hline UIC 10 & Entrepreneurial culture in universities & Fayolle and Redford (2014) \\
\hline UIC 11 & Publication opportunities with industry & $\begin{array}{l}\text { Lundberg et al. (2006) and Ankrah } \\
\text { and Omar (2015) }\end{array}$ \\
\hline
\end{tabular}

(Continued on next page) 
Table 1. Continued

\begin{tabular}{|c|c|c|}
\hline Code & UIC Factors & Literature Sources \\
\hline $\mathrm{UIC} 12$ & $4 \mid R$ project exercises in classrooms & $\begin{array}{l}\text { Hariharasudan and Kot (2018) and } \\
\text { Hussin (2018) }\end{array}$ \\
\hline $\mathrm{UIC} 13$ & Patenting opportunities & $\begin{array}{l}\text { Marotta et al. (2007), Wu, Welch } \\
\text { and Huang (2015) and Ankrah and } \\
\text { Omar (2015) }\end{array}$ \\
\hline $\mathrm{UICl} 4$ & $\begin{array}{l}\text { 4IR training programmes opportunities } \\
\text { for students }\end{array}$ & $\begin{array}{l}\text { Bozeman and Gaughan (2007) and } \\
\text { Hussin (2018) }\end{array}$ \\
\hline UIC 15 & Student's exposure to innovative ideas & $\begin{array}{l}\text { Bozeman and Gaughan (2007) and } \\
\text { Hussin (2018) }\end{array}$ \\
\hline $\mathrm{UIC} 16$ & Involvement in $4 \mathrm{IR}$ projects & $\begin{array}{l}\text { Bozeman and Gaughan (2007) and } \\
\text { Hussin (2018) }\end{array}$ \\
\hline
\end{tabular}

\section{RESEARCH METHODOLOGY}

\section{The Delphi Process}

For this research study, a qualitative Delphi approach was conducted to validate the UIC factors identified from the literature. According to Häder and Häder (1995) and Aigbavboa (2014), the Delphi technique is designed to get experts' opinions on matters that are still gaining relevance, such as the objectives of this study. In a typical Delphi approach, experts respond to questions and submit their responses to the researcher who collates and analyses the information to determine the central and extreme tendencies (Aigbavboa, 2014). For this study, the experts were anonymous throughout the Delphi process and could resubmit their opinions as many times as possible until consensus was reached. Similar to how it was used during the Cold War, the Delphi process helps to make predictions and projections concerning a specific subject matter. In this study, due to the advent of the 4IR, the pressures on universities to collaborate with the industry and related sectors have gained momentum; hence, this research determines the roles of UIC in driving the 4IR initiative in South Africa. Over time, the Delphi method has become a systematic thinking tool and has gained recognition from experts across several disciplines for generating credible outcomes and provoking relevant discussions (Agumba and Mosunda, 2013; Ameyaw et al., 2016; Tengan and Aigbavboa, 2018; Pouratashi and Zamani, 2019).

This research is expected to stimulate extensive studies on graduate employability (Employability 4.0) in South Africa and beyond, hence, the Delphi method is relevant to the realisation of the study's objectives. The opinions of experts make the Delphi method a robust and credible one as professional opinions are obtained, which ensure the reliability of the study (Habibi, Sarafrazi and Izadyar, 2014). Another major strength of the Delphi technique is that it stems from the constructivist paradigm by cutting across both the quantitative and qualitative methods of data collection and analysis (Sarantakos, 2005; Green, 2014; Hanapi et al., 2018). This allows for the results and conclusions of the research 
to be generally represented to the wider population. For this study, two rounds of the Delphi process were conducted before experts reached a consensus on the various factors, with the strength of the Delphi method lying in the various rounds (iterations) which help in initial feedback and dissemination of subsequent rounds for further review and opinions (Hanapi et al., 2018; Stitt-Gohdes and Crews, 2004). Generally, the strength of qualitative research such as the Delphi technique is based on the methodological rigour in conducting such a process (Leung, 2015). For this study, a detailed procedure was adopted as shown in Figure 2. It is also critical to note that during the Delphi process, more attention should be given to the group responses (convergence of ideas) rather than the individual response. To this end, several parameters (median and interquartile deviation [IQD]) were adopted to measure consistencies, central tendencies, and hence, determine consensus.

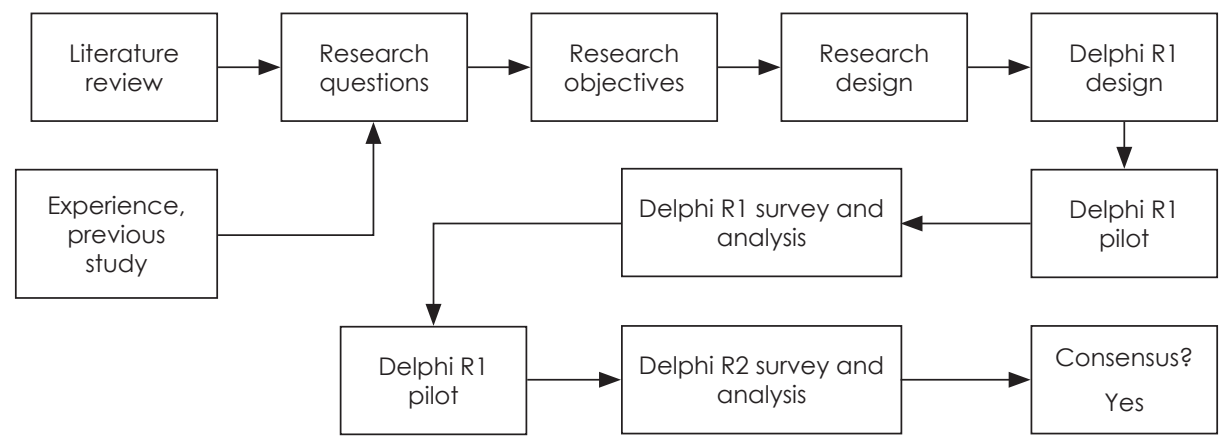

Figure 2. Delphi design for this study

\section{Selection of Delphi experts for the study}

According to Aigbavboa (2014) and Hanapi et al. (2018), Delphi experts refer to a panel of knowledgeable individuals who are selected for a specific study based on certain criteria (criterion sampling). Based on the fact that the quality of opinions depends on experts' knowledgeability, this research presents the demographic characteristics of the selected panel to portray their knowledge and expertise to justify their selection. Over time, researchers have provided several criteria in deciding who should be called an expert. In the previous studies of Adler and Ziglio (1996) and Rogers and Lopez (2002), to be called an expert, an individual should possess some of the following, including understanding the subject matter in question; author of publications relating to the subject in question; attendance of conference and workshop relating to the subject in question; willingness to participate in the study at that point in time; willingness to partake in several rounds when required; good communicators to avoid a slow process; employed with an accredited institution of higher education; satisfactory number of years of experience in the construction industry; member of an academic committee; possess an academic degree in a related discipline; registered with an accredited professional body and several others. This aligns with the previous studies of Alomari, Gambatese and Tymvios (2018), Hallowell 
and Gambatese (2010) and Hallowell, Esmaeili and Chinowsky (2011). However, across various studies, it has been agreed that the researcher has the autonomy to decide who should be called an expert based on any of the listed criteria or, as stated by the researcher, as it suits the study. For this study, an expert was required to satisfy three or more of the following criteria that include: possess at least a bachelor's degree in a built environment discipline; employed with either a construction firm or an accredited university in South Africa; possess at least five years working experience within a construction firm or an accredited university in South Africa; or registered with an accredited professional body and an author of publications relating to the built environment as shown in Table 2. From Table 2, the 14 experts who completed the Delphi process satisfied three or more of the stated criteria.

Table 2. Assessment of Delphi expert qualifications

\begin{tabular}{|c|c|c|c|c|c|c|c|c|c|c|c|c|c|c|c|}
\hline $\mathrm{S} / \mathrm{N}$ & $\begin{array}{l}\text { Eligibility criteria } \\
\text { for Experts }\end{array}$ & E1 & E2 & E3 & E4 & E5 & E6 & E7 & E8 & E9 & E10 & E11 & E12 & E13 & E14 \\
\hline 1 & $\begin{array}{l}\text { Possess at least a } \\
\text { bachelor's degree }\end{array}$ & $x$ & $x$ & $x$ & $x$ & $x$ & $x$ & $x$ & $x$ & $x$ & $x$ & $x$ & $x$ & $x$ & $x$ \\
\hline 2. & $\begin{array}{l}\text { Currently employed } \\
\text { with a tertiary } \\
\text { institution or } \\
\text { professional in the } \\
\text { construction industry }\end{array}$ & $x$ & $x$ & & $x$ & & & $x$ & $x$ & $x$ & $x$ & $x$ & & $x$ & $x$ \\
\hline 3. & $\begin{array}{l}\text { At least five } \\
\text { years of working } \\
\text { experience with a } \\
\text { tertiary institution or } \\
\text { construction industry }\end{array}$ & $x$ & $x$ & $x$ & $x$ & $x$ & $x$ & $x$ & $x$ & $x$ & $x$ & $x$ & $x$ & $x$ & $x$ \\
\hline 4. & $\begin{array}{l}\text { Affiliated with } \\
\text { professional bodies }\end{array}$ & $x$ & $x$ & $x$ & $x$ & $x$ & $x$ & $x$ & & $x$ & $x$ & $x$ & $x$ & $x$ & \\
\hline 5. & $\begin{array}{l}\text { Author or co-author } \\
\text { of a peer-reviewed } \\
\text { publication }\end{array}$ & $x$ & $x$ & $x$ & $x$ & & $x$ & $x$ & $x$ & & $x$ & & $x$ & & $x$ \\
\hline & Total & 5 & 5 & 4 & 5 & 3 & 4 & 5 & 4 & 4 & 5 & 4 & 4 & 4 & 4 \\
\hline
\end{tabular}

\section{Determination of the Delphi panel size}

Because the Delphi approach is more qualitative than quantitative, fewer participants or experts are required for the process. Over the years, numerous researchers have recommended several sample sizes required for a Delphi process. Dalkey and Helmer (1963) suggested seven experts, Cavalli-Sforza and Ortolano (1984) recommended 8 to 12 experts, Phillips (2000) stated between 7 to 12 experts, while Andranovich (1995) and Skulmoski, Hartman and Krahn (2007) proposed 10 to 15 participants if the panel of experts are of a homogeneous sample and possess similar backgrounds. Due to time constraints and an unpredictable schedule of experts, a small sample (14 experts from both the construction industry and academics) was considered for this research. 
The 14 experts agreed to participate in the Delphi study after they received a comprehensive description (requirements or instructions) of the process. Before the study began, the selected experts were requested to forward their curriculum vitae (CV) to ascertain if they meet the qualification threshold for this study, after which they received the first-round questionnaire survey, which comprised of both open-ended and closed questions, with the option of rankings and stating their opinions. Both the first and second rounds of the Delphi questionnaires can be found in the Appendix section.

\section{Delphi experts' information}

As stated earlier, one of the criteria to be an expert was to possess at least a bachelor's degree in a discipline within the built environment. Following an analysis of the experts' CV, all 14 experts possessed at least a bachelor's degree as shown in Table 3.

Table 3. Panel of experts' qualifications

\begin{tabular}{lc}
\hline Highest Qualification & Number of Experts \\
\hline Doctor of Philosophy (PhD) & 5 \\
Master's degree (MSC and MEng) & 7 \\
Bachelor's degree (BEng) & 2 \\
\hline Total & 14 \\
\hline Notes: MSC (Master of Science): MEng (Master of Engineering): BEng (Bachelor of Engineering).
\end{tabular}

Based on their academic qualifications, five of the experts possessed a doctorate; seven of the experts had a master's degree while two of the experts possessed a bachelor's degree. This shows that around $86 \%$ of the experts possessed post-graduate degrees, which highlights the credibility of this study. More so, these high academic qualifications of the experts boost the quality and reputability of this study's Delphi process. Secondly, the experts were required to possess a built environment background. As shown in Table 4, the 14 experts represent most of the various disciplines in the built environment.

Table 4. Panel of experts' field of specialisation

\begin{tabular}{lc}
\hline Field of Specialisation & Number of Experts \\
\hline Architecture & 2 \\
Quantity surveying & 1 \\
Construction project management & 2 \\
Engineering (civil, mechanical and electrical) & 9 \\
\hline Total & 14 \\
\hline
\end{tabular}


Based on their academic qualifications, two of the experts possess a background in architecture, one expert was from quantity surveying; two of the experts where from construction project management while nine of the experts were of engineering background (civil, mechanical and electrical). Further analysis of experts' CV showed that eight of the experts were from higher institutions in South Africa while six experts were from the construction industry. Experts were also required to have at least five years of working experience with an academic institution or the construction industry. As shown in Table 5, the 14 experts all possessed a significant number of work experiences in their spheres of influence.

Table 5. Panel of experts' years of experience

\begin{tabular}{lc}
\hline Years of Experience & Number of Experts \\
\hline 5 years & 1 \\
6 years to 10 years & 7 \\
11 years to 20 years & 3 \\
21 years to 30 years & 2 \\
Over 31 years & 1 \\
\hline & 14 \\
\hline
\end{tabular}

Based on their years of experience, one expert had five years of experience, seven had 6 years to 10 years of experience, three had 11 years to 20 years of experience, two had 21 years to 30 years of experience and one expert had more than 31 years of working experience. Additionally, experts were required to be members of recognised and accredited professional bodies. Hence, five of the experts were registered with the Engineering Council of South Africa, two were registered with the South African Council for the Project and Construction Management Professions, two were registered with the South African Institution of Civil Engineering and one was registered with Project Management South Africa. Finally, most of the authors were authors and co-authors of peerreviewed publications within the built environment disciplines and have presented at academic conferences, webinars and seminars.

\section{Determining consensus from the Delphi Study}

As stated earlier, the main aim of the Delphi study was to attain consensus among the selected experts. Over time, many researchers have established several parameters for reaching consensus. According to Holey et al. (2007), a consensus is achieved when there is a convergence (agreements) of opinions among experts. Rayens and Hahn (2000) suggested that consensus is achieved by recording the median and standard deviations (SD) values where a decrease in SD between rounds indicates higher levels of agreement among experts. In addition, Aigbavboa (2014) proposed that for consensus to be reached, the IQD should be less than or equal to 1, signifying that over $60 \%$ of the experts were 
largely positive or largely negative in their responses toward a specific issue. For this study, a consensus was achieved when the IQD $=0.00$ or $\leq 1$. The consensus scales adopted for this study are shown in Table 6.

Table 6. Consensus scales for this study

\begin{tabular}{clccc}
\hline No. & Consensus strength & Median & Mean & IQD \\
\hline 1. & Strong & $9-10$ & $8-10$ & $\leq 1$ and $\geq 80 \%$ (8-10) \\
2. & Good & $7-8.99$ & $6-7.99$ & $\geq 1.1 \leq 2$ and $\geq 60 \% \leq 79 \%$ (6-7.99) \\
3. & Weak & $\leq 6.99$ & $\leq 5.99$ & $\geq 2.1 \leq 3$ and $\leq 59 \%$ (5.99) \\
\hline
\end{tabular}

\section{PRESENTATION OF FINDINGS}

\section{Delphi Round 1}

This research aims to determine the roles of UIC in driving the 4IR initiative in South Africa. Rankings were achieved using a 10-point Likert scale of "No significance", "Low significance", "Medium significance", "High significance" and "Very high significance". While "Very high significance" had the highest weighting (9 and 10), "No significance" was assigned the lowest weighting (1 and 2). A total of 16 UIC factors were identified from literature and government reports, as shown in Table 1. More so, six of the factors - student's exposure to 4IR ideas, patenting opportunities, 4IR project exercises in classrooms, research grants from industry, 4IR job opportunities for graduates, and scholarship opportunities for students were highly selected by the experts based on the median score of 9.00. From the six factors, none achieved consensus based on IQD scores of above 1.0, as shown in Figure 3. Likewise, involvement in 4IR projects, 4IR training programmes opportunities for students, publication opportunities with industry, entrepreneurial culture in universities, networking activities with industry professionals, guest speakers from industry, vocational training, industry mentoring for students and field trips to industry recorded median scores of 8.00 each. More so, no new factors were introduced by the experts. 


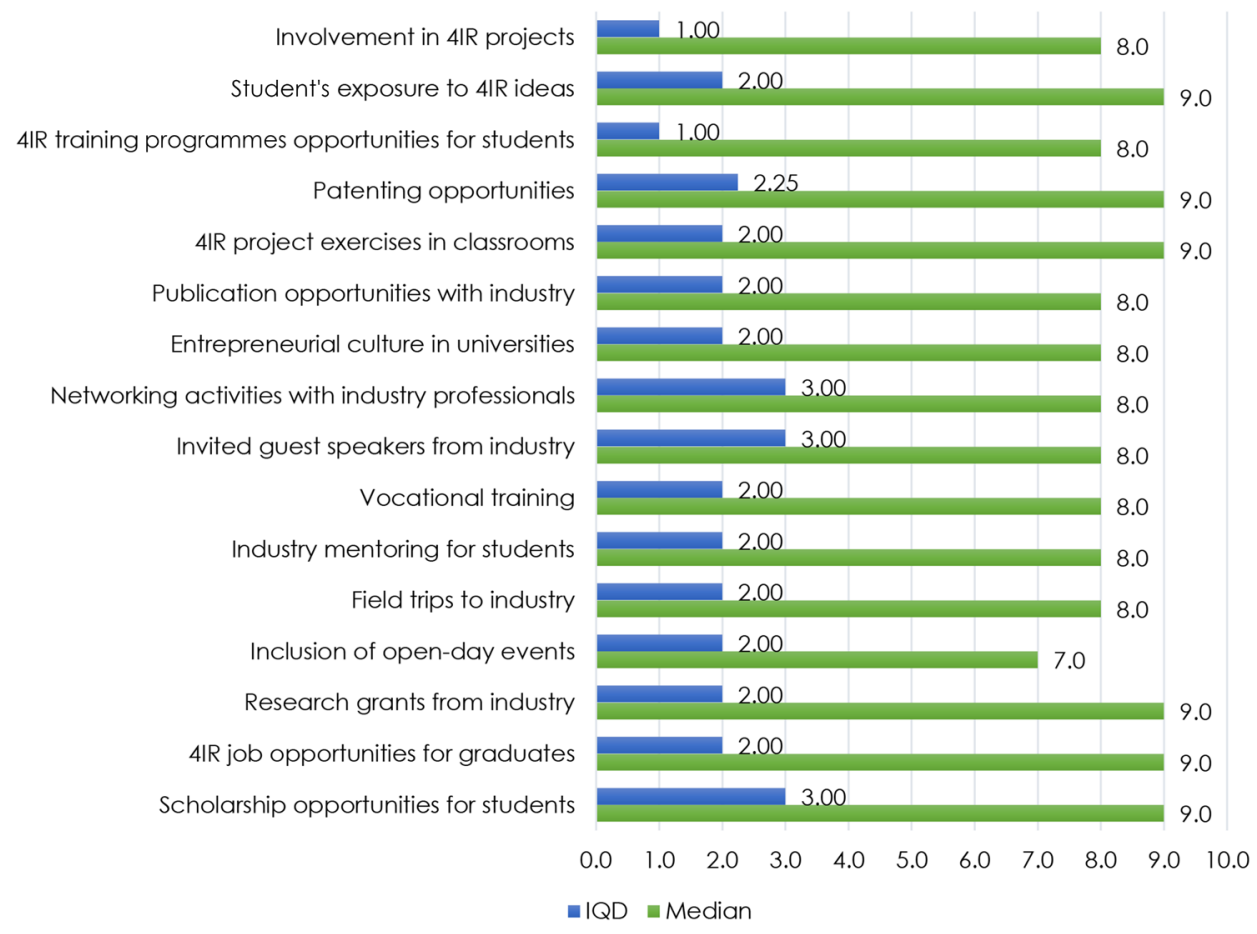

Figure 3. List of university-industry factors

\section{Delphi Round 2}

Shortly after the completion of the first round, the researcher analysed the data and sent out the second-round questionnaire. In this round, the experts were required to do one of the following - accept the group media value by returning the questionnaires to the researcher without making any changes; maintain their original responses and choosing a new response (and providing explanations for making those changes). Table 7 presents a summary of the second-round responses with the median, mean, standard deviation and IQD scores duly recorded. 
Table 7. UIC factors

\begin{tabular}{lcccc}
\hline UIC Factors & Median & Mean $(\overline{\mathbf{x}})$ & SD $(\sigma \mathbf{X})$ & IQD \\
\hline Scholarship opportunities for students & 9 & 8.93 & 0.73 & 0.00 \\
4IR job opportunities for graduates & 9 & 8.79 & 0.80 & 0.00 \\
Research grants from industry & 9 & 8.43 & 1.50 & 0.75 \\
Inclusion of open-day events & 7 & 6.71 & 0.83 & 0.75 \\
Field trips to industry & 8 & 7.64 & 1.01 & 0.00 \\
Industry mentoring for students & 8 & 7.79 & 0.43 & 0.00 \\
Vocational training & 8 & 7.57 & 0.94 & 0.00 \\
Invited guest speakers from industry & 8 & 7.71 & 0.99 & 0.00 \\
Networking activities with industry & 9 & 8.50 & 1.56 & 0.00 \\
professionals & & & & \\
Entrepreneurial culture in universities & 8 & 7.79 & 1.37 & 0.00 \\
Publication opportunities with industry & 8 & 7.43 & 1.40 & 0.00 \\
4IR project exercises in classrooms & 9 & 8.29 & 1.33 & 0.75 \\
Patenting opportunities & 9 & 8.64 & 1.08 & 0.00 \\
4IR training programmes opportunities & 9 & 8.50 & 1.40 & 0.00 \\
for students & & & & 0.00 \\
Student's exposure to innovative ideas & 9 & 8.43 & 1.40 & 0.00 \\
Involvement in 4IR projects & 8 & 7.79 & 0.80 & \\
\hline
\end{tabular}

\section{DISCUSSION OF FINDINGS}

After the successful completion of the second-round Delphi questionnaire, it was found that all 16 factors achieved good consensus. Hence, there was no need for a third or fourth round process. Findings emanating from the Delphi study suggest that the factors that underwent both rounds mostly resonate with what has been proposed by the South African government during recent 4IRdriven initiatives as well as several existing literatures. As observed from Table 7 , all 16 factors had median scores between 7.00 and 9.00 , indicating very high significance rankings by the experts. Scholarship opportunities for students having a median value of 9.00 and a mean value of 8.93 are one of the possible student benefits of UIC. The high rankings of this factor are in agreement with the existing studies of Belfield (2012) and Guimón (2013). According to both sets of research, through collaborations, students are offered local, national and multinational scholarship opportunities to carry out research or study specific areas that are of interest to companies. More so, through UIC, students are provided with 4IR job opportunities in various capacities and this was confirmed as the factor possessed a median value of 9.00 and a mean value of 8.79 . With the establishment of the 4IRSA, it is expected that the skills revolution, which Ramaphosa spoke about during the inaugural Digital Economy Summit, will 
produce students who are digitally-savvy and multiskilled to handle job 4IR positions after graduation such as data mining, coding of data, cloud computing, cybersecurity, computer programming and design of algorithms, among many others. There exists a strong consensus among experts on research grants from the industry with a median value of 9.00 and mean value of 8.43 . This aligns with the previous studies of Bozeman and Gaughan (2007) and Ivascu, Cirjaliu and Draghici (2016), who opined that through collaborations, industry is obligated in some cases to offer research grants to institutions of higher learning to conduct relevant researches. This in turn benefits students as they are presented with several research-based opportunities to explore the body of knowledge in their quest to solve socio-economic problems through their research outputs (Link, Siegel and Bozeman, 2017). Networking activities with industry professionals with a median value of 9.00 and mean value of 8.50 were also ranked highly, which resonates with the study by Aasheim, Li and Williams (2009), who noted that through effective UIC, students are offered several opportunities of networking with professionals from the industry. These networking opportunities provide students with long-lasting personal relationships with professionals, developing fresh ideas, enhancing their reputation, receiving career advice and support, gaining different perspectives toward issues and even getting job opportunities.

Additionally, 4IR project exercises in classrooms with a median value of 9.00 and mean value of 8.29 were ranked highly by experts and rightly so. With the advent of the 4IR, collaborating with industry or 4IR-driven establishment helps institutions of higher learning to introduce 4IR-inspired pedagogical approaches such as smart classrooms to facilitate an interactive and stimulating experience for students. 4IR project exercises in classrooms can be carried out by smart and interactive boards, multimedia control mechanisms and audio/ video elements. Through these, courses such as computer programming, artificial intelligence (AI), algorithms, data coding, and several 4IR components can be effectively taught (Hariharasudan and Kot, 2018; Hussin, 2018). Patenting opportunities with a median value of 9.00 and mean value of 8.64 is another UIC benefit for built environment students. This finding is in tandem with the submission of Wu, Welch and Huang (2015) who posited that through collaborations, students are offered research and creative opportunities to create and invent ideas. By protecting their intellectual properties (patenting), students' employability is improved and such patents can generate revenue for their institutions and themselves (WU, Welch and Huang, 2015). Finally, both 4IR training programme opportunities for students and student's exposure to innovative ideas obtained median values of 9.00 and mean values of 8.50 and 8.43 , respectively. These findings are in line with the existing studies of Bozeman and Gaughan (2007) and Hussin (2018). These studies both suggested that through collaborations, learning opportunities are created for students through hands-on learning and project-based learning. These opportunities allow students to apply their skills and knowledge in solving problems, which improve their employability skills (Bozeman and Gaughan, 2007; Hussin, 2018). Finally, there exists a strong consensus among experts on the remaining factors with median values of 8.00 . These include field trips to industry, industry mentoring for students, vocational training, guest speakers from industry, entrepreneurial culture in universities, publication opportunities with industry and involvement in 4IR projects. These outlined factors were resonated in existing literature such as that of Hariharasudan and Kot (2018) and Hussin (2018). 


\section{CONCLUSION AND RECOMMENDATIONS}

As the world gears up for the 4IR, Africa is also prepping for this age of innovation, with South Africa as one of its leading voices. Under the leadership of President Cyril Ramaphosa, the "4IR" theme has become the leading mantra of new policy initiatives designed to move the nation forward and out of the economic crisis. One of the ways of positioning South Africa to leverage on the opportunities presented by this wave of revolution is to foster collaborations between higher educational institutions (universities) and the construction industry (public and private sector). Just recently, the nation established the 4IRSA, which is designed to stimulate a national dialogue to leverage on the opportunities provided by the $4 I R$ for the benefit of the nation. This partnership seeks active participation from the government, industry, researchers, small businesses, labour, academia, civil society, international organisations and the media. It is against this backdrop that this study examines the roles of collaboration (specifically between universityindustry) in driving the 4IR initiative in South Africa as well as developing the employability of built environment graduates. In achieving the objectives of this study, a qualitative Delphi approach was adopted to validate these factors as universities across South Africa and beyond take measures in preparing students for this latest wave of innovation. Built environment experts who satisfied the listed criteria for participation were drawn from both academics and industry practice. After two rounds of the Delphi process, very high consensus was reached on all 16 factors identified with an IQD value of 0.00. The study, therefore, achieved its stated objectives of validating these UIC factors among experts after two Delphi iterations.

While this study was conducted in South Africa, its findings resonate with existing literature across the globe and hence, generalisation across the African continent and beyond is possible. Therefore, one of the recommendations for this study is that educational institutions should intensify collaborations with the industry by creating avenues for students to experience industrial training with present-day 4IR-driven sectors such as the construction industry, which has begun the adoption of $4 \mathrm{IR}$ elements into its processes to improve efficiency and productivity. Another implication for institutions of higher learning is that to further understand the intricacies and dynamics of the technologies propelling the 4IR, they need to make a conscientious effort to organise workshops, openday events and training programmes so that students are exposed to the latest innovations surrounding the $4 I R$ era. As discussed in this study, UIC provides several benefits for institutions of higher learning and hence its students, as it provides access to 4IR technologies and applications, industrial data, scientific knowledge, research grants and employment opportunities for students before and after graduation. Due to the findings of this study, it is recommended for universities to continuously seek collaborations with the industry to leverage on the opportunities such linkages present students as they are regarded as the future custodians of the industry. More so, universities can invite guest speakers from industry to deliver topics surrounding the 4IR, which can go a long way in preparing students for the next wave of digitalisation.

While this study highlights UIC benefits in driving the 4IR initiative, the findings of this study also have some viable implications for construction organisations and professionals as they constantly seek collaborations with academia. 
As governments across the globe begin the process of formulating policies and initiatives to leverage the opportunities presented by the new wave of digitalisation, industry parastatals are compelled to join forces with universities. This is because, in developing countries and beyond, government relies so much on research conducted by universities. Therefore, the implication of these government policies means that industries are compelled to collaborate with universities to benefit from the policy-execution processes, and hence, maintain their competitive advantage. More so, by embarking on collaborations, the industry can gain accessibility to the best students and talent for internship purposes and recruitment possibilities. Another motivation for industry to collaborate is the access gained to a wider range of research networks across different fields, which can lead to exponential growth and improved corporate image as they work in tandem with reputable universities. Furthermore, industry professionals have an excellent opportunity to upgrade their qualifications, which is another implication of establishing collaborations with academia.

Despite the numerous benefits, UIC is not without its barriers. Firstly, institutions of higher learning face the risk of deviating from their long-term objectives due to pressures of achieving short-term ones that are made possible through collaborations with the industry. Secondly, higher institutions could encounter difficulties during the commercialisation of technologies developed due to possible confidentiality agreements signed with industry partners. This could result in a clash of interest for the universities who face the daunting task of upholding their mission statement and fulfilling the obligations of collaborations. Finally, collaborations for universities can bring about distraction from core educational activities as they face the risk of spending more time and resources in chasing down these partnerships. Although UIC can be challenging for both parties, the benefits certainly outweigh the risks involved.

\section{ACKNOWLEDGEMENTS}

The authors would like to thank Enago (www.enago.com) for the English language review.

\section{REFERENCES}

4IRSA (2019). Partnership for the 4th Industrial Revolution in South Africa. Available at: https://www.4irsa.org/purpose-objectives.

Aasheim, C.L., Li, L. and Williams, S. (2009). Knowledge and skill requirements for entry-level information technology workers: A comparison of industry and academia. Journal of Information Systems Education, 20(3): 349-356.

Adler, M. and Ziglio, E. (1996). Gazing into the Oracle: The Delphi Method and its Application to Social Policy and Public Health. London: Jessica Kingsley Publishers.

Agumba, J. and Musonda, I. (2013). Experience of using Delphi method in construction health and safety research. Paper presented at the Seventh International Conference on Construction in the 21st Century (CITC-VII) "Challenges in Innovation, Integration and Collaboration in Construction and Engineering". Bangkok, Thailand, 19-21 December. 
Aigbavboa, C.O. (2014). An integrated beneficiary centred satisfaction model for publicly funded housing schemes in South Africa. PhD diss. University of Johannesburg.

Aliu, J. and Aigbavboa, C. (2018). Equipping graduates for the future: The need for higher institutions to collaborate. Industrial Engineering (IE) and Operations Management (OM), 57(3): 121-133.

Alomari, K.A., Gambatese, J.A. and Tymvios, N. (2018). Risk perception comparison among construction safety professionals: Delphi perspective. Journal of Construction Engineering and Management, 144(12): 04018107. https://doi .org/10.1061/(ASCE)CO.1943-7862.0001565.

Ameyaw, E.E., Hu, Y., Shan, M., Chan, A.P. and Le, Y. (2016). Application of Delphi method in construction engineering and management research: a quantitative perspective. Journal of Civil Engineering and Management, 22(8): 991-1000. https://doi.org/10.3846/13923730.2014.945953.

Andranovich, G. (1995). Developing Community Participation and Consensus: The Delphi Technique. Pullman, Washington: USDA. Available at: https://hdl. handle.net/2376/4399.

Ankrah, S. and Omar, A.T. (2015). Universities-industry collaboration: A systematic review. Scandinavian Journal of Management, 31 (3): 387-408. https://doi. org/10.1016/j.scaman.2015.02.003.

Bamberger, Y. and Tal, T. (2008). Multiple outcomes of class visits to natural history museums: The students' view. Journal of Science Education and Technology, 17(3): 274-284. https://doi.org/10.1007/s10956-008-9097-3.

Belfield, H. (2012). Making Industry-University Partnerships Work: Lesson from Successful Collaborations. Brussels, Belgium: Science/Business Innovation Board AISBL.

Bozeman, B. and Gaughan, M. (2007). Impacts of grants and contracts on academic researchers' interactions with industry. Research Policy, 36(5): 694-707. https://doi.org/10.1016/j.respol.2007.01.007.

Buckley, C. (1995). Delphi: A methodology for preferences more than predictions. Library Management, 16(7): 16-19. https://doi.org/10.1108/014351295100 93737.

Cavalli-Sforza, V. and Ortolano, L. (1984). Delphi forecasts of land use: Transportation interactions. Journal of Transportation Engineering, 110(3): 324-339. https://doi.org/10.1061/(ASCE)0733-947X(1984)110:3(324).

Dalkey, N. and Helmer, O. (1963). An experimental application of the Delphi method to the use of experts. Journal of the Institute of Management Science, 9(3): 458-467. https://doi.org/10.1287/mnsc.9.3.458.

DeWitt, J. and Storksdieck, M. (2008). A short review of school field trips: Key findings from the past and implications for the future. Visitor Studies, 11(2): 181-197. https://doi.org/10.1080/10645570802355562.

Dori, Y.J. and Tal, R.T. (2000). Formal and informal collaborative projects: Engaging in industry with environmental awareness. Science Education, 84(1): 95-113. https://doi.org/10.1002/(SICI) 1098-237X(200001)84:1<95::AIDSCE7>3.0.CO;2-W.

Etzkowitz, H. and Zhou, C. (2017). The Triple Helix: University-Industry-Government Innovation and Entrepreneurship. Oxon/New York: Routledge. https://doi .org/10.4324/9781315620183. 
Fayolle, A. and Redford, D.T., eds. (2014). Introduction: Towards more entrepreneurial universities; Myth or reality? In Handbook on the Entrepreneurial University. Cheltenham, UK/Northampton, MA: Edward Elgar.

Green, R.A. (2014). The Delphi technique in educational research. Sage Open, 4(2): 1-8. https://doi.org/10.1177/2158244014529773.

Guimón, J. (2013). Promoting university-industry collaboration in developing countries. The Innovation Policy Platform, 3: 12-48.

Habibi, A., Sarafrazi, A. and Izadyar, S. (2014). Delphi technique theoretical framework in qualitative research. The International Journal of Engineering and Science, 3(4): 8-13.

Häder, M. and Häder, S. (1995). Delphi and cognitive psychology: An approach to the theoretical foundation of the Delphi method. ZUMA Nachrichten, 19(37): 8-34.

Hallowell, M.R. and Gambatese, J.A. (2010). Qualitative research: Application of the Delphi method to CEM research. Journal of Construction Engineering and Management, 136(1): 99-107.

Hallowell, M., Esmaeili, B. and Chinowsky, P. (2011). Safety risk interactions among highway construction work tasks. Construction Management and Economics, 29(4): 417-429. https://doi.org/10.1080/01446193.2011.552512.

Hanapi, Z., Mamat, A.B., Zulkifli, R.M., Sharif, M.S. and Hasnan, K.A. (2018). Development of employability skills measurement model among engineering graduates of community college using Delphi technique and confirmatory factor analysis. Advanced Science Letters, 24(4): 2660-2664. https://doi.org/10.1166/asl.2018.11028.

Hariharasudan, A. and Kot, S. (2018). A scoping review on Digital English and Education 4.0 for industry 4.0. Social Sciences, 7(11): 227. https://doi.org/ 10.3390/socsci71110227.

Holey, E.A., Feeley, J.L., Dixon, J. and Whittaker, V.J. (2007). An exploration of the use of simple statistics to measure consensus and stability in Delphi studies. BMC Medical Research Methodology, 7: 52. https://doi.org/10.1186/1471 $-2288-7-52$.

Hussin, A.A. (2018). Education 4.0 made simple: Ideas for teaching. International Journal of Education and Literacy Studies, 6(3): 92-98. https://doi.org/10 .7575/aiac.ijels.v.6n.3p.92.

Hyland, T. (2019). Vocational Studies, Lifelong Learning and Social Values: Investigating Education, Training and NVQs Under the New Deal. Oxon/New York: Routledge. https://doi.org/10.4324/9780429432439.

Ivascu, L., Cirjaliu, B. and Draghici, A. (2016). Business model for the universityindustry collaboration in open innovation. Procedia Economics and Finance, 39: 674-678. https://doi.org/10.1016/S2212-5671(16)30288-X

Kamp, A. and Milke, M. (2019). Times of Change in the Engineering Industry: Practising Engineers, Undergraduate Students and Mentoring. Edited by B.E. Stalder and C. Nägele. Hamburg: European Conference on Educational Research.

Lawson, R., Papadopoulos, T., Taylor, T., Fallshaw, E. and Zanko, M. (2011). Professional learning in the business curriculum: Engaging industry, academics and students. Asian Social Science, 7(4): 61-68. https://doi.org/10.5539/ass. v7n4p61. 
Leung, L. (2015). Validity, reliability, and generalizability in qualitative research. Journal of Family Medicine and Primary Care, 4(3): 324-327. https://doi.org/ 10.4103/2249-4863.161306.

Leydesdorff, L. (2013). The triple helix of university-industry-government relations. In E.G. Carayannis (ed.), Encyclopedia of Creativity, Innovation, and Entrepreneurship. New York: Springer. https://doi.org/10.1007/978-1-4614 -3858-8_452.

Link, A.N., Siegel, D.S. and Bozeman, B. (2017). An empirical analysis of the propensity of academics to engage in formal university technology transfer. In D.B Audretsch and A.N. Link (eds.), Universities and the Entrepreneurial Ecosystem. Edward Elgar Publishing, 97-111. https://doi.org/10.4337/978178 6432797.00014.

Lundberg, J., Tomson, G., Lundkvist, I., Skår, J. and Brommels, M. (2006). Collaboration uncovered: Exploring the adequacy of measuring university-industry collaboration through co-authorship and funding. Scientometrics, 69(3): 575-589. https://doi.org/10.1007/s11192-006-0170-5.

Marotta, D., Mark, M., Blom, A. and Thorn, K. (2007). Human Capital and UniversityIndustry Linkages' Role in Fostering Firm Innovation: An Empirical Study of Chile and Colombia. Washington DC: World Bank.

Mei, X.Y. (2019). Gaps in tourism education and workforce needs: Attracting and educating the right people. Current Issues in Tourism, 22(12): 1400-1404. https://doi.org/10.1080/13683500.2017.1402870.

Nyawo, J.C. and Mashau, P. (2019). An evaluation of the role of the culturalheritage industry in the economy of South Africa. African Journal of Hospitality, Tourism and Leisure, 8(5): 1-13.

Phillips, R. (2000). New Applications for the Delphi Technique. San Diego: Pfeiffer and Company.

Plutino, A. (2016). Anything can happen out there: A holistic approach to field trips. In C. Goria, O. Speicher and S. Stollhans (eds.), Innovative Language Teaching and Learning at University: Enhancing Participation and Collaboration. Dublin: Research-publishing.net, 113-120. https://doi.org/10 $.14705 /$ rpnet.2016.000412.

Pouratashi, M. and Zamani, A. (2019). University and graduates employability: Academics' views regarding university activities (the case of Iran). Higher Education, Skills and Work-Based Learning, 9(3): 290-304. https://doi.org/ 10.1108/HESWBL-12-2017-0103.

Ramaphosa, C. (2019). Address by President Cyril Ramaphosa to the 1st South African Digital Economy Summit. Gallagher Convention Centre, Johannesburg, 5 July. Available at: https://www.gov.za/speeches/president-cyril-ramaphosa -south-african-digital-economy-summit-5-jul-2019-0000

Rayens, M.K. and Hahn, E.J. (2000). Building consensus using the policy Delphi method. Policy, Politics and Nursing Practice, 1(4): 308-315. https://doi .org/10.1177/152715440000100409.

Rinaldi, C., Cavicchi, A., Spigarelli, F., Lacchè, L. and Rubens, A. (2018). Universities and smart specialisation strategy: From third mission to sustainable development co-creation. International Journal of Sustainability in Higher Education, 19(1): 67-84. https://doi.org/10.1108/IJSHE-04-2016-0070.

Roberts, P.J. and Kozlowski, R.Z. (2001). Open day review: Bridging the gap between academia and industry. Drug Discovery Today, 6(1): 19-20. https://doi.org/10.1016/S1359-6446(00)01625-1. 
Rogers, M.R. and Lopez, E.C. (2002). Identifying critical cross-cultural school psychology competencies. Journal of School Psychology, 40(2): 115-141. https://doi.org/10.1016/S0022-4405(02)00093-6.

Sarantakos, S. (2005). Social Research. 3rd Ed. Basingstoke, UK: Palgrave Macmillan.

Short, F. and Lloyd, T. (2017). Taking the student to the world: Teaching sensitive issues using field trips. Psychology Teaching Review, 23(1): 49-55.

Skulmoski, G.J., Hartman, F.T. and Krahn, J. (2007). The Delphi method for graduate research. Journal of Information Technology Education: Research, 6(1): 1-21. https://doi.org/10.28945/199.

Stitt-Gohdes, W.L. and Crews, T.B. (2004). The Delphi technique: A research strategy for career and technical education. Journal of Career and Technical Education, 20(2): 55-67. https://doi.org/10.21061/jcte.v20i2.636.

Tengan, C. and Aigbavboa, C. (2018). Validating factors influencing monitoring and evaluation in the Ghanaian construction industry: A Delphi study approach. International Journal of Construction Management, 10(2): 1-12.

Tseng, F.C., Huang, M.H. and Chen, D.Z. (2018). Factors of university-industry collaboration affecting university innovation performance. The Journal of Technology Transfer, 45: 560-577. https://doi.org/10.1007/s10961-018-9656-6

Wu, Y., Welch, E.W. and Huang, W.L. (2015). Commercialization of university inventions: Individual and institutional factors affecting licensing of university patents. Technovation, 36-37: 12-25. https://doi.org/10.1016/ j.technovation.2014.09.004. 